IMRE JÓZSEF BALÁZS

\title{
LE SURRÉALISME EN 1947: THE EXPORT AND EXCHANGE OF IDEAS IN POST-WAR INTERNATIONAL SURREALISM ${ }^{1}$
}

The International Surrealist Exhibition of 1947 entitled Le Surréalisme en 1947, organized at the Maeght gallery in Paris, may be considered as a conversion point in the history of Surrealism, opening up (short-term) possibilities for new groups and generations desiring to join the movement, while at the same time it represented the closing moment for several small-scale Surrealist projects set up by individuals and groups. Using the opportunity presented by the exhibition, young French and Belgian Surrealists turned against the group of artists gathered around Breton and initiated the establishment of a group of revolutionary Surrealists. Shortly afterwards, the relationship worsened between Breton and those members of the group personally committed to upholding the values of the pre-World War Surrealist group, and new exclusions and severances occurred as a result - not for the first or last time in the history of the movement. At the same time, one of the novelties of the exhibition, the relatively substantial presence of Eastern and Central European artists and theoreticians, proved to be an unrepeatable event, as a result of the consolidation of the Soviet-type cultural politics in Romania, Hungary and Czechoslovakia, where political power soon drastically restricted the possibilities of contacts with Paris, stigmatising all sort of avant-garde artistic activity in these countries.

The direction of Surrealism in the post-war period was outlined by André Breton's works like Mad love, Arcane 17 and The Anthology of Black Humour, focusing increasingly on an inward journey, a sort of utopia or, rather, eupsychia that related the changes in the external world to a change within the self. This new direction was connected to the surrealists' conflictual experiences regarding the Communist party and the war. In developing the new theories of Surrealism, Breton found allies in authors like Pierre Mabille, who, in 1940, published Le miroir du merveilleux, a kind of anthology including comments, where the term "marvellous" exemplifies a prominent feature in the works of the early stages of surrealism, which gained more and more importance during the 1940s. Authors like Victor Brauner and Jacques Hérold, Gherasim Luca and Árpád Mezei developed an increasingly strong and intense relation to Breton's theories during and immediately after the war.

\footnotetext{
${ }^{1}$ Research supported by a Bolyai Research Fellowship of the Hungarian Academy of Sciences.
} 
As current research projects on Surrealism have already pointed out, the history of the current can be described as a space of a constant and mutual exchange of ideas. Delia Ungureanu has also pointed out that this exchange of ideas goes, in fact, far beyond the Surrealist groups themselves:

Surrealism was a group practice that benefited from a great world network of agents and mediators even beyond what the surrealists themselves imagined. This history challenges traditional notions of direct influence and unidirectional transfer, including the portrayal of surrealism in terms of in-group dynamics [...]. Instead, we find networks of mutual exchange and transformation, which far exceed the confines of the organized surrealist groups, with their constant struggles over hierarchies, subordination, and authority ${ }^{2}$.

It is important, however, to document the exchange of ideas in its in-group aspects in order to see how major events like an international surrealist exhibition may trigger new ideas and new intellectual geographies. The 1947 exhibition represents, in many ways, a milestone in the history of international Surrealism, and an example of what Delia Ungureanu calls "challenges of unidirectional transfer". In my article I will examine, from the point of view of the authors participating in the exhibition, involved in the preparations and submitting pieces for the catalogue, the kind of importance that was attached to the act of participating itself, and how these authors positioned themselves relative to Surrealism before and after the event. My goal is also to outline the Surrealist network structure of which, due to the above-mentioned cultural and political shifts, only the Western European nodes had remained active by the end of the 1940s.

\section{The historical context and concept of organizing the exhibition}

The exhibition of 1947 documented the reorganisation of Surrealism and its newly accentuated presence in Paris after the years of the Second World War, during which André Breton sought refuge first in Marseille and then in North America. The movement had to respond, on the one hand, to analyses inspired by Maurice Nadeau's History of Surrealism ${ }^{3}$, which suggested that the movement - as well as the group - had ceased to exist. On the other hand, the movement had to find its place in the contemporary intellectual milieu in France dominated by the presence of Communists and Existentialists, as a kind of countermeasure to the country's war experience.

In June 1947, the group also drew up a manifesto entitled "Rupture inaugurale", in which it tried not only to clarify its approach to politics but also to

\footnotetext{
${ }^{2}$ Delia Ungureanu, From Paris to Tlön: Surrealism as World Literature, New York, Bloomsbury Academic, 2018, p. 3.

${ }^{3}$ Maurice Nadeau, Histoire du surréalisme, Paris, Seuil, 1945.
} 
respond to contemporary criticism regarding the activity of the group. The primary message of the manifesto, signed by fifty authors, is the announcement of abstention from any party politics, while the group continues to regard the revolutionary activity of the working class as close to its own programme. One of the fundamental questions in the manifesto is of a moral character. It starts from the premise that the capitalist state system must cease to exist as a result of historical necessity and targeted political activity. For this reason, the proletarian revolution is a desirable turn, but not the goal itself ${ }^{4}$.

An important part of the manifesto is the argument for the need to create a new myth - a doctrine that can replace Christianity and, in a moral sense, provide a more progressive foundation for the new society. The reason for this is that the signatories of the manifesto did not believe that the transformation of the social/economic system would automatically result in a moral and intellectual change as well. The above explanation makes it clear where Surrealism tried to position itself in the post-war environment: it saw itself as a leftist, revolutionary movement willing to co-operate with various parties (the anarchists and the Trotskyites are specifically mentioned in the manifesto), but only on a voluntary and sovereign basis, while firmly rejecting Stalinism. Surrealism would play a role in transforming mentality and morality. The last part of the manifesto refers back to those conceptual factors that André Breton added to the Surrealist myths in his various works. A desire for myth, black humour, objective chance and the like, according to the signatories' belief, may be the essential elements for accessing a new psychological dimension, the aim of which is to overthrow the previous seemingly insoluble opposition between desire and necessity ${ }^{5}$.

Therefore, the option suggested by Breton, also reflected in the design of the 1947 exhibition, was the demonstration of a belief in the positive, healing character of myth and the principle of Eros, and the exploration of this principle after the group had refused direct participation in politics. By this time, Surrealists had very concrete experiences of the limited possibilities of arts defined by party politics, and they had rejected the concept of party art in the name of spiritual freedom.

The 1947 exhibition followed the script of an initiation ritual. Breton had prepared a detailed preliminary plan, which was sent to the group members and the international network of sympathizers. One of the most important authors of the exhibition was Jacques Hérold, born in Romania and living in Paris since 1930, who displayed the myth of the Great Transparent One in his memorable creation. Apart from Hérold, his compatriot Victor Brauner also fit well into the system of views that had taken shape as a result of the magical turn of Surrealism.

\footnotetext{
4 "Inaugural rupture", in Michael Richardson and Krzysztof Fijalkowski (eds.), Surrealism Against the Current. Tracts and Declarations, London-Sterling, Pluto Press, 2001, p. 44.

${ }^{5}$ Ibidem, p. 46.
} 
The reaction of the audience was controversial. Although the surrealists' success was unquestionable, in many cases the echoes pushed the current toward its past: it was regarded as something that was undoubtedly a great product of French culture, but seemed more acceptable out of habit rather than due to its values.

According to the summary written by Sarane Alexandrian, then a member of the group, the point of the exhibition was the creation of a collective myth. The walk through the exhibition area was planned in such a way that the visitors became participants in the myth as they were progressing: ascending movements, delusions, tentative movements appealing to visceral anxiety reactions were all written into the exhibition space. The exhibition presented works by eighty-seven artists representing twenty-four countries. Among these, there were many young artists at the beginning of their career who at that time were approaching the system of views of Surrealism, according to Alexandrian ${ }^{6}$. Béla Bán and Endre Bálint, the two Hungarian participants in the exhibition, were probably considered to be among these.

Marcel Jean, a veteran member of the group at the time of the event, reports himself on the concept and preparation of the exhibition and its catalogue. $\mathrm{He}$ connects the basic idea of the exhibition to Breton's earlier trip to Haiti, and regards the predominance of the mythical and magical themes as the result of this experience. Jean also offers a detailed account of the moments of spiritual progression/initiation, and also mentions some anecdotal episodes that arise from the perspective of the eyewitness and insider, such as the unrealized plan of the "Surrealist kitchen", or the collection of the painters called "Surrealists against their will", which, in the end, was not exhibited either. Jean writes about the billiard table set up in accordance with Duchamp's idea, from the top of which the billiard balls suddenly disappeared, migrating into the visitors' pockets as souvenirs ${ }^{7}$.

Alexandrian's and Jean's reports on the exhibition are ultimately defined by the writers' insider status, as well as by the fact that both of them would soon enter into a conflict with Breton and leave the Surrealist group. The narrative that the exhibition fits into becomes part of a story of decline, not because of the concept and the partial success of the exhibition, but as a result of the ensuing debates. Although the Surrealist group remained active, publishing works and organising exhibitions, its membership changed significantly after the Second World War.

Alyce Mahon's counter-narrative, which greatly appreciates the performance of the Surrealists in the spirit of the politics of Eros after 1938, indicates the 1968 Parisian student riots as the end of the story and as the moment of realisation of a

\footnotetext{
${ }^{6}$ Sarane Alexandrian, Surrealist Art, London, Thames and Hudson, 1970, pp. 190-194.

${ }^{7}$ Marcel Jean in cooperation with Árpád Mezei, Histoire de la peinture surréaliste, Paris, Seuil, 1959, pp. 336-344.
} 
Surrealist utopia of some kind ${ }^{8}$. During the Paris riots, Surrealist slogans and sentences were indeed propagated in the demonstrations and several Surrealist artists also joined the demonstrations. A specific addition to this interpretation is Marcel Jean's short and succinct response to a survey questioning the validity and presence of Surrealism in 1971, which is "May 1968" .

\section{The preparations: surveys and letters}

Surrealists enjoyed taking surveys. At the end of June 1947, that is, on the days preceding the opening of the international exhibition, the international sympathizers of Surrealism received a questionnaire on letterhead paper containing eight questions posed by Cause, the Surrealist "secretariat" comprising three members whose names were displayed on the header: Sarane Alexandrian, Georges Henein and Henri Pastoureau. The questions are related to the present and possible tasks of Surrealism. Árpád Mezei received the questionnaire from Georges Henein. His answer to the letter is unknown at present, but on $10^{\text {th }} \mathrm{July}$ he reports on this development to Claude Serbanne, a mutual acquaintance:

Henein replied. He also seems to exist in two copies, and one of these is the official secretary of the Surrealist movement. He even sent a questionnaire of eight questions. If I were serious about answering the questions, I would need about 2000 pages $^{10}$.

Alexandrian connects the event of contacting Gherasim Luca to the same questionnaire. In a letter dated 29 June 1947, Luca writes a detailed response to Alexandrian on his position, including many references to his works published at that time and to the activities of the Surrealist group in Bucharest. Although he considers the survey necessary, he calls for a quick step forward from the static/statistical mapping of "where we stand" to the concrete and pragmatic steps of "what to do" .

If we are looking for the motivations behind the setting up of Cause, we may assume that Breton's overwork was probably the trigger: at this time, after having returned home to France, Breton was assaulted by his "fans" and by many young men belonging to the contemporary bohemian society, whose main interest was not necessarily the essential program of Surrealism. ${ }^{12}$ Based on their participation in the exhibition catalogue, we may assume that artists such as Mezei or the Bucharest Surrealists eventually passed through the filter that ended in some sort of

\footnotetext{
${ }^{8}$ Alyce Mahon, Surrealism and the Politics of Eros, 1938-1968, New York, Thames \& Hudson, 2005 .

${ }^{9}$ Arnost Budik, "Enquète sur le surréalisme d'aujourd'hui", Gradiva, 1971, 1, p. 34.

${ }^{10}$ Letter from Árpád Mezei to Claude Serbanne, 10 July 1947. Árpád Mezei’s estate, OSZK Manuscript Archive, Budapest. (Own translation, IJB)

${ }^{11}$ The complete letter was published by Sarane Alexandrian in his volume L'evolution de Gherasim Luca à Paris, Bucharest, Vinea-ICARE, 2006, pp. 9-12.

${ }^{12}$ Sarane Alexandrian, L'évolution de Gherasim Luca, p. 8.
} 
clearing up of the 1947 turmoil, as well as in many older and newer members leaving the group.

Breton transferred a fragment of the text entitled "Le sable nocturne", written by the Bucharest group, directly into his introduction to the 1947 exhibition catalogue, as a thought coinciding with the central question of the exhibition: "According to the lucky wording by our friends in Bucharest, 'knowing through unknowing' [connaissance par la méconnaissance] remains an important Surrealist slogan"13.

On the basis of several reports on the preparations for the exhibition, we now know about the feverish efforts and constant gatherings during the preceding few weeks. As an additional detail, some artists including Victor Brauner and the Bucharest Surrealist group had had a relatively clear concept of and information on the planned exhibition for as far back as a year earlier, since the summer of 1946. As early as August 1946, Luca and Gellu Naum exchanged letters about the plan to be drafted; according to Luca's summary, Brauner speaks about the overall image of the exhibition as a church of freedom/ heresy and expects collective/anonymous works from his friends in Bucharest ${ }^{14}$. In a letter written to Brauner on 12 March 1947, Luca still complains that the official invitation from Breton has not arrived. The plan, however, with which the group would participate in the exhibition, is now in place ${ }^{15}$. In a single week the events would accelerate, and on $20^{\text {th }}$ March Luca writes that they have sent their collective text Le sable nocturne for the exhibition catalogue by air mail ${ }^{16}$. Thus, the text sent had preserved the anonymous, collective nature called for in the original plan.

In the case of the "nocturnal sand" 17 experiment, the insertion of objective chance into the plan, or the radicality of the endeavour, besides which the text serves solely as a kind of documentation, obviously gained Breton's appreciation. However, a direct continuation proved impossible: not having received a passport from the Romanian authorities, Luca and Trost attempted to cross the border illegally at the end of 1947 , without success. It was only in 1950 that they could once again write detailed, sincere, uncensored letters from Israel to Paris, trying to rekindle lost connections, but by this time the circumstances were different from those in 1947. In a letter dated 30 October 1950, Luca writes to Brauner, from Tel Aviv, that he really trusts Breton's ideological "purity" and regrets Brauner and

\footnotetext{
${ }^{13}$ André Breton, "Devant le rideau", in André Breton and Marcel Duchamp (eds.), Le Surréalisme en 1947, Paris, Maeght Éditeur, 1947. (Own translation, IJB.)

${ }^{14}$ Letter from Gherasim Luca to Gellu Naum, August 1946, "Athanor: Caietele Fundației Gellu Naum", 2008, 2, pp. 26-27.

${ }^{15}$ Letter from Gherasim Luca to Victor Brauner, 12 March 1947, in Victor Brauner, Écrits et correspondances 1938-1948, Paris, Centre Pompidou-INHA, 2005, pp. 226-227.

${ }^{16}$ Letter from Gherasim Luca to Victor Brauner, 20 March 1947, in Victor Brauner, Écrits..., p. 227. The authors of Le sable nocturne: Gherasim Luca, Gellu Naum, Paul Păun, Virgil Teodorescu, Trost.

17 See the interpretative description in Sarane Alexandrian, Le surréalisme et le rêve, Paris, Gallimard, 1974, p. 225.
} 
Breton's divergence, especially since their friendship seemed to be at its peak at the time of the 1947 exhibition ${ }^{18}$. 1947, Maeght Gallery: the last virtual meeting point for the entire company.

\section{The threads converging in Budapest, with Árpád Mezei}

A letter written by Árpád Mezei and dated February 6, 1947, was preserved in the Breton archives. ${ }^{19}$ Here he mentions the invitation received via Marcel Jean and tries to respond to it by presenting a study plan which, in his view, is both a reconsideration of the system of sciences and a theory of Surrealism. As a result of this letter, Mezei's "Liberté du langage" was published in the exhibition catalogue.

Breton could feel that Mezei's contribution at that time was of major importance to the movement, at least in three respects: 1. Mezei's theoretical inclination, which, in its partiality, showed a similar direction to Breton's; 2. His interest in and vast knowledge of hermetic sciences, as manifested in the works he produced in collaboration with Marcel Jean; 3 . His being a Maldoror expert: Mezei and Jean's volume entitled Maldoror was finalized and published in Paris in the year of the exhibition ${ }^{20}$, and a part of the volume, namely an analysis of the sixth book, was published in the exhibition catalogue. Consequently, Mezei is one of the exceptional authors who had not one, but two entries included in the publication. In his study, Mezei projects onto Surrealism the analogy from natural science according to which light behaves both as a wave and as a particle at the same time. In Mezei's thought experiment, this principle is extended to meanings as well, outlining an equivalence relation that follows a dialectic logic of some sort. Mezei considers Surrealism suitable to emphasise this so-called vision according to the principle of equivalence, and also to suggest the dual nature of reality by a synthesis of the conscious and unconscious spheres. According to Mezei, both words and reality are multi-dimensional - and they are in an analogous relation with each other, according to the way described above; in Mezei's opinion, therefore, hermetic theory based on the above principle can contribute to strengthening this recognition. It is clear that Mezei's presence in the catalogue, as well as Béla Bán's and Endre Bálint's participation in the exhibition, was mediated by Marcel Jean. However, another piece of the preliminary history of their participation is that Jean did not meet the two young painters while in Budapest, where he lived between 1938 and 1945, and until leaving Budapest he had considered that Hungarian paintings were pervaded more by abstractionism, at the

\footnotetext{
${ }^{18}$ Letter from Gherasim Luca to Victor Brauner, 30 October 1950. Bibliothèque Kandinsky, inv. 8818-763.

19 Árpád Mezei, Plan d'un article, 6 February 1947. Fonds André Breton 10592, Boîte de la vente, http://www.andrebreton.fr/fr/item/?GCOI=56600100591490. Accessed February 26, 2019.

${ }^{20}$ Marcel Jean et Árpád Mezei, Maldoror: Essai sur Lautréamont et son cuvre, Paris, Pavois, 1947.
} 
expense of Surrealism. It may be supposed that his position somewhat changed in the summer of 1947, but in April 1947 he still writes to Mezei that he considers him the only Hungarian Surrealist ${ }^{21}$. One month later, as per Mezei's observation, he expects Bálint and Bán to arrive in Paris - some of the aspects of the meetings are later reported by Bán in his letters sent to Budapest. From these letters, we learn that Bán and his group initiated contact with both abstract and Surrealist galleries in Paris, which caused some technical difficulties, since the planned exhibitions of these galleries were to take place simultaneously. In May, Jean is looking forward to meeting the young painters, whom, even though he does not know them yet, he trusts as members of the European School:

As about the painters you have mentioned - I am looking forward to their visit. [...] Otherwise, I think that historically Hungarians have been more prominent in poetry and philosophy than in fine arts; of course this does not mean that there are no good Hungarian painters at present, but I do not know enough about the ones you wrote about. As far as Rozsda and Barta are concerned, back then it seemed to me that they were far from Surrealism, but that does not mean that they could not have moved in that direction? ${ }^{22}$

As we know, Bán and Bálint finally did participate in the international Surrealist exhibition, and their perspective can be outlined on the basis of their reports on the exhibition.

\section{The testimonies of Béla Bán and Endre Bálint}

In a letter to Imre Pán dated 3 June 1947, Endre Bálint indicates that the preparations for the exhibition are under way, and he proudly writes that Breton has chosen one of his paintings to be included in the material of the exhibition ${ }^{23}$. In the same letter he also indicates that he is planning to write about the exhibition for a Hungarian newspaper. The young painter did write about his impressions of the exhibition, and in 1972 he also included the text in his volume entitled Hazugságok naplójából [From the Diary of Lies] ${ }^{24}$.

In his notes, Endre Bálint jots down his personal experiences first, exemplifying the reality and physical experience of anxiety and speaking about the effect the Surrealist exhibition had on him, described as similar to the experience of

\footnotetext{
${ }^{21}$ Letter from Marcel Jean to Árpád Mezei, 11 April 1947, Árpád Mezei estate, OSZK Manuscript Archive

${ }^{22}$ Letter from Marcel Jean to Árpád Mezei, 12 May [1947], Árpád Mezei estate, OSZK Manuscript Archive. (Own translation, IJB)

${ }^{23}$ Letter from Endre Bálint to Imre Pán, in Péter György és Gábor Pataki, Az Európai Iskola és az Elvont Müvészek csoportja [The European School and the Group of Abstract Artists], Budapest, Corvina, 1990, p. 132.

${ }^{24}$ Endre Bálint, Hazugságok naplójából [From the Diary of Lies], Budapest, Magvető, 1972.
} 
a visit to an old city park panopticon ${ }^{25}$. As Bálint points out, in the context of war physical existence exceeds its usual proportions and seeks a new balance. This is also one of the important directions of Surrealism when experimenting with the sensation of space:

the illusion of infinite space and microscopic "objectivity" in the representation of objects, this major contradiction that can only be explained by a proportional shift: the magnified character of the fear of death is a constant acknowledgment of its proximity $^{26}$.

Thus, the experience of war is an important element in Bálint's interpretation of the exhibition: he identifies war as some sort of spirit of the age, or at least as a pervasive experience whose dark reality legitimizes the disturbing, sometimes grim colours of the Surrealist exhibition. Besides the Czech Toyen who, according to Bálint, provides the base note of the exhibition by representing the "average", the latter mentions the names of four more artists among the Surrealists: Joan Miró ("who knows that behind the surface there lurks a world of ancient cultures, still alive, and therefore possible to portray - and this is why his mythical figures are so convincing"); Hans Arp, who is mentioned as an example of reconciling the spirit of abstraction and Surrealism (from the perspective of contemporary Hungarian art, this is a key issue causing many rifts); Salvador Dalí, the great absentee; and Max Ernst, whom Bálint calls "the most significant one among the Surrealists", but whose two works included in the exhibition are not among the most successful ${ }^{27}$.

However, the anecdotal aspects of the exhibition are rich in detail. The billiard table, also mentioned by Jean and Alexandrian, appears here as being in use, although the inclusion of such effects seems frivolous to the young Hungarian painter. We should remember, however, that in his opinion the most important factor contributing to the overall effect is the constant presence of the experience of the proximity to death.

Béla Bán, who participates in the exhibition as Endre Bálint's fellow scholarship student, also writes a description that remained in manuscript and was published only in 1984 by Gábor Pataki and Péter György in the periodical "Ars Hungarica" 28 . This piece of reporting is somewhat more objective than Bálint's, and it was most certainly written with the aim of being published in a newspaper. Bán's stance is the same as Bálint's in that he also seeks the essence of Surrealism beyond the games and anecdotal elements, as if separated from these, and he regards the organisers' "tricks" as a means to attract the audience. In this regard, he

\footnotetext{
${ }^{25}$ Endre Bálint, "Exposition internationale du surréalisme Paris, Galerie Maeght", in Endre Bálint, Hazugságok naplójából, p. 69.

${ }^{26}$ Ibidem, p. 70.

${ }^{27}$ Ibidem, p. 71.

28 Béla Bán, "A nemzetközi szürrealista kiállítás Párisban” ["International Surrealist Exhibition in Paris"], Ars Hungarica, 1984, 2, pp. 289-290.
} 
considers the experiment successful. As he remarks, despite the high entry fees, the exhibition is constantly packed with visitors.

Bán writes about some of the exhibited works in more detail than Bálint, combining technical descriptions and interpretations to describe works by Yves Tanguy, Max Ernst, Joan Miró, Picasso and Marcel Duchamp. In addition to these, he reflects positively on his encounter with the outstanding works of the following authors: Arp, Matta, Toyen, Stirsky, Brauner, Gorky, Man Ray, Baskine. In their cases, he specifically praises their qualities as painters, while their conceptual framework appears to be secondary to these qualities: "in our opinion, among the many artists who represent Surrealism, these are the ones that do so by means of art, and free from literature-like nuances" 29 .

Bán also lists all Hungarian participants in the exhibition by name, as artists who ensure the Hungarian presence with "honesty and painterly qualities". Besides Endre Bálint and himself, he also mentions the Parisian-Hungarian Ervin Marton, who is in fact described in the exhibition catalogue as coming from "Hongrie", as well as Henri Nouveau (Henrik Neugeboren), born in Braşov and former resident of Budapest, who, according to the catalogue, represents France ${ }^{30}$.

In his writing, Bán summarises the contemporary goals of Surrealism, but also envisions the emergence of his own art and the "art of the future" as heading towards another, synthetic direction, perhaps under the influence of the developments in Hungary, as well as of the talks and events taking place in Paris ${ }^{31}$. In a letter written in Paris, dated September 1947, Bán calls himself a Communist, and this - in the context of the "Rupture inaugurale" manifesto - also indicatesone of the reasons why Bán considered himself justified to keep himself at arm's length from the Surrealist group of Paris ${ }^{32}$.

Béla Bán's oeuvre, as noted by Gábor Pataki and Péter György, had developed in the spirit of a sincere endeavour to create "liberal" socialist art until 1949; afterwards, however, as a result of his dogmatic socialist realism period, he wrote himself out of the history of fine art, writing himself in among the privileged of power relations ${ }^{33}$. Later, moreover, he was also affected by the news embargo imposed on the emigrants of $1956^{34}$. As opposed to Bán, Endre Bálint became part of another alternative story - (also) in line with the Hungarian counter-culture

\footnotetext{
${ }^{29}$ Ibidem.

${ }^{30}$ The list of Hungarian-related works in the catalog: Ban, L'homme errant; Balint, Solitude; Marton, $\mathrm{Nu}$ assis; Nouveau: Joséphine, Le roi de Thulé. See also 1947. Exposition internationale du Surréalisme, Fiches intérieures du catalogue, http://www.andrebreton.fr/fr/item/?GCOI=56600100506400\#. Accessed February 26, 2019.

${ }^{31}$ Béla Bán, “A nemzetközi szürrealista”, p. 290.

${ }^{32}$ Letter from Béla Bán to Imre Pán, 10 September 1947, Ars Hungarica, 1984, 2, p. 291.

${ }^{33}$ Péter György és Gábor Pataki, "Dokumentumok Béla Bán hagyatékából” ["Documents of the Béla Bán Legacy”], Ars Hungarica, 1984, 2, p. 283.

34 György Várkonyi, Egy életmü újrafelfedezése [Redescovering a Life Work], http://www.virtuartnet.hu/frontend_dev.php/szerzo/ban-bela/eletrajz. Accessed February 26, 2019.
} 
narratives of the 1960s and 1970s. Together with some other painters and art historians, Bálint is among those who represent the link between the Hungarian avant-garde and neo-avant-garde generations $\mathrm{s}^{35}$.

\section{Concluding remarks}

The 1947 Surrealist exhibition and preceding preparations represented one of the last opportunities for "free" expression for Central and Eastern European artists, before the establishment of the Stalinist cultural politics. For example, the text Le sable nocturne, written by the Romanian Surrealist group and published in the exhibition catalogue, is the last publication of this kind, next to the manyauthored Éloge de Malombra, signed by all the group members. In Budapest, the European School would cease its activity shortly afterwards. The study of the history of the exhibition and its echo provides indication as to how the history of Hungarian fine art and literature would have evolved after a period of relative freedom between 1945 and 1947, in the absence of the intervention of an aggressive, monopolizing kind of cultural politics. Undoubtedly, the unique combination and alliance between abstraction and Surrealism promoted by Ernő Kállai and the European School would have remained an important feature of Hungarian art. At the same time, it is also likely that the leftist artists in Hungary would still have had to face the dilemma of direct political action versus artistic autonomy, given that this dilemma led to sharp debates even in the politically freer post-war circumstances in France. In Hungary, however, such a debate was out of question after 1948. The issue was settled by the dominant power for the ensuing years and decades.

As the examples cited above show, the 1947 exhibition may serve as a model for describing mutual exchanges of ideas, since it was an exchange process that occurred within a network of artists who communicated with each other directly, but also through network nodes situated in France. We can see how the radical ideas of the Bucharest Surrealists, including the anonymous character of their contribution, resonated with Breton's ideas about the exhibition - and also how Árpád Mezei's theoretical inclinations became important for highlighting the initiatory aspects of the event. The accounts of young Central-European painters about the exhibited works also reveal the dilemmas that were encoded into the differences in the intellectual and political background of the participants, and that soon afterwards led to divergences and conflicts within the Surrealist movement.

\footnotetext{
${ }^{35}$ Péter György, Az elsüllyedt sziget [The Sunken Island], Budapest, Képzőművészeti Kiadó, 1992, p. 24.
} 


\section{BIBLIOGRAPHY}

ALEXANDRIAN, Sarane, L'evolution de Gherasim Luca à Paris, Bucharest, Vinea-ICARE, 2006. ALEXANDRIAN, Sarane, Le surréalisme et le rêve, Paris, Gallimard, 1974.

ALEXANDRIAN, Sarane, Surrealist Art, London, Thames and Hudson, 1970.

BÁLINT, Endre, Hazugságok naplójából [From the Diary of Lies], Budapest: Magvető, 1972.

BÁN, Béla, “A nemzetközi szürrealista kiállítás Párisban” [„International Surrealist Exhibition in Paris"], Ars Hungarica, 1984, 2, pp. 289-290.

BRAUNER, Victor, Écrits et correspondances 1938-1948, Paris, Centre Pompidou-INHA, 2005.

BRETON, André, "Devant le rideau", in André Breton and Marcel Duchamp (eds.), Le Surréalisme en 1947, Paris, Maeght Éditeur, 1947.

BUDIK, Arnost, "Enquète sur le surréalisme d'aujourd'hui", Gradiva, 1971, 1, p. 34.

GYÖRGY, Péter és PATAKI, Gábor, "Dokumentumok Béla Bán hagyatékából” ["Documents of the Béla Bán Legacy”], Ars Hungarica, 1984, 2, p. 283.

GYÖRGY, Péter és PATAKI, Gábor, Az Európai Iskola és az Elvont Müvészek csoportja [The European School and the Group of Abstract Artists], Budapest, Corvina, 1990.

GYÖRGY, Péter, Az elsüllyedt sziget [The Sunken Island], Budapest, Képzőmüvészeti Kiadó, 1992.

JEAN, Marcel et MEZEI, Árpád, Maldoror: Essai sur Lautréamont et son œuvre, Paris, Pavois, 1947.

JEAN, Marcel, in cooperation with Árpád Mezei, Histoire de la peinture surréaliste, Paris, Seuil, 1959.

MAHON, Alyce, Surrealism and the Politics of Eros, 1938-1968, New York, Thames \& Hudson, 2005.

MEZEI, Arpad, Plan d'un article, 6 February 1947. Fonds André Breton 10592, Boîte de la vente, http://www.andrebreton.fr/fr/item/?GCOI=56600100591490. Accessed February 26, 2019.

NADEAU, Maurice, Histoire du surréalisme, Paris, Seuil, 1945.

RICHARDSON, Michael and FIJALKOWSKI, Krzysztof (eds.), Surrealism Against the Current. Tracts and Declarations, London-Sterling, Pluto Press, 2001.

UNGUREANU, Delia, From Paris to Tlön: Surrealism as World Literature, New York, Bloomsbury Academic, 2018.

VÁRKONYI, György, Egy életmü újrafelfedezése [Redescovering a Life Work], http://www.virtuartnet.hu/frontend_dev.php/szerzo/ban-bela/eletrajz. Accessed February 26, 2019.

\section{LE SURRÉALISME EN 1947: THE EXPORT AND EXCHANGE OF IDEAS IN POST-WAR INTERNATIONAL SURREALISM \\ (Abstract)}

Post-war Surrealism was often considered by contemporaries as no more than an appendix to the current's glorious interwar period. However, the international dimension and impact of Surrealism was prominently acknowledged after the Second World War. The present article identifies the 1947 International Surrealist Exhibition as a site and model of mutual intellectual exchange and examines, from the point of view of the authors participating in the exhibition, the sort of importance that was attached to the participation itself, and the way in which these authors positioned themselves relative to Surrealism, before and after the event. Through these contributions and their preparation documented in letter exchanges, a post-war Surrealist network structure is outlined.

Keywords: Surrealism, network, mutual exchange, exhibition, Le Surréalisme en 1947, Bucharest Surrealist group, European School, post-war period. 


\section{SUPRAREALISMUL ÎN 1947: EXPORTUL ȘI SCHIMBUL DE IDEI ÎN SUPRAREALISMUL POSTBELIC INTERNAȚIONAL \\ (Rezumat)}

Suprarealismul postbelic a fost adeseori considerat de contemporanii săi drept o simplă anexă a glorioasei perioade interbelice a curentului. Totuși, caracterul și impactul internaționale ale suprarealismului s-au făcut remarcate după cel de-al Doilea Război Mondial. Acest articol, fundamentat pe ideea că expoziția internațională Suprarealismul în 1947 a constituit o platformă şi un model de interacţiune intelectuală autentică, examinează, pornind de la punctele de vedere exprimate de participanți, tipul de importanță acordat prezenței la expoziție, precum şi modurile în care autorii sau raportat la suprarealism înaintea și în urma desfășurării evenimentului. Prin intermediul respectivelor raportări, exprimate prin schimburi de scrisori, o întreagă rețea a suprarealismului postbelic poate fi reliefată.

Cuvinte-cheie: suprarealism, rețea, interacțiuni, expoziție, Suprarealismul în 1947, grupul suprarealist de la București, Școala Europeană, perioada postbelică. 